\title{
WHEN REGIONS COLLIDE: IN WHAT SENSE A NEW 'REGIONAL PROBLEM’?
}

\author{
* John Harrison \\ Department of Geography \\ School of Social, Political and Geographical Sciences \\ Loughborough University \\ Loughborough \\ United Kingdom \\ LE11 3TU \\ $+44(0) 1509228198$ \\ j.harrison4@lboro.ac.uk

\section{Anna Growe} \\ Institut für Kulturgeographie \\ Albert Ludwigs Universität Freiburg \\ Fakultät für Umwelt und Natürliche Ressourcen \\ D-79085 Freiburg \\ Deutschland \\ +49(0)76120397874 \\ anna.growe@geographie.uni-freiburg.de
}

*Author for correspondence

This paper has now been published and should be cited as follows:

Harrison J and Growe A 2014 When regions collide: in what sense a new 'regional problem'? Environment and Planning A 46(10) 2332-2352.

http://www.envplan.com/abstract.cgi?id=a130341p 
Abstract Going beyond the territorial/relational divide in regional studies requires researchers to do more than examine the extent to which territoriality and relationality are complementary alternatives. The variety of networked regional spaces means it is intellectually unsustainable to simply relate a single networked regional space to territoryscale without first considering how networked regional spaces interact. Illustrated through the experience of Germany, our paper demonstrates that interaction between different networked regional spaces (e.g. city-regions and cross-border regions) is resulting in new networked regional imaginaries (e.g. cross-border metropolitan regions). Its overall aim is to show that the production of entirely new networked spaces can assist in overcoming the contradictions present in one configuration of regions, but this only serves to create a new 'regional problem' requiring ever more complex configurations of regions.

Key words Territorial/relational divide; cross-border metropolitan region; cityregionalism; Germany; Leitbild 


\section{WHEN REGIONS COLLIDE: IN WHAT SENSE A NEW 'REGIONAL PROBLEM’?}

"Regions, perceived as core sites of competitiveness, governance, planning, and identity have become major players in the building of an integrated Europe as well as the restructuring of national administrative and political territories." (Lagendijk, 2005: 83)

"We should collectively invest in the plural of 'regional logics', tailoring usage to the problems at hand, rather than in a singular logic that simply replaces the romance of the nation-state with an equally simple and one-size-fits-all alternative geographical unit of account." (Agnew, 2013: 15)

\section{INTRODUCTION: WHAT KIND OF 'REGIONAL WORLD'?}

Regions are integral to accounts of 'getting on' in our globalizing world. Yet, if the importance of regions is enduring the type of region being considered is certainly not. For those engaged in documenting the resurgence of regions a central question remains the degree to which the region, long-considered to be a territorially-fixed and bounded unit, is best conceptualised as the outcome of relationally-networked processes which render obsolete any notion of the region as a "meaningful territorial entity" (Allen and Cochrane, 2007: 1163).

Within the literature this dichotomy between territorial and networked regional spaces has been clearly evident, with new spatial terminology distinguishing between 'spaces of places'/'spaces of flows' (Castells, 1996), 'spaces of regionalism'/'regional spaces' (Jones and MacLeod, 2004), 'usual'/'unusual' regions (Deas and Lord, 2006), and 'regional world'/'new regional world' (Harrison, 2013) or 'regional worlds' (Jones and Paasi, 2013). In each case, the latter is becoming an increasingly significant feature of our globalizing world. Nevertheless, the conceptual neatness provided by these couplings obscures the variety and 
assortment of networked regional spaces that are actually emerging. Furthermore, dissensus arises when determining if emerging networked regional geographies are evidencing a transition, where newly dominant relational approaches usurp the formerly dominant territorial perspective.

The configuration of these new networked regional spaces is also not uniform. In fact, we can observe a variety of different networked regional spaces, differentiated both by the scale at which they operate (supranational or subnational) and the logic (geoeconomic or geopolitical) underpinning their existence (Figure 1). This is significant because if one looks at the often cited map of 146 new relationally networked regional spaces in Europe by Deas and Lord (2006: 1852) this actually amounts to a very selective and partial picture - of geopolitical relationally-networked regional spaces. This illustrates how the starting point(s) for considering new relationally-networked regional geographies have been, we would argue, quite distinct and separate. But it also helps us to recognise how there has been significant movement over the past decade, with those networked geographies sharing a logic (geoeconomic/geoeconomic) or scale (supranational/subnational) being considered much more closely in theory and practice. Let us take city-regions and cross-border regions to illustrate our point. The rise of city-regions was framed around a geoeconomic logic (Scott, 2001). This is now complemented by a critical body of literature which considers their geopolitical importance (Harrison and Hoyler, 2013), meaning it is now "increasingly difficult disentangle the new economic geography of city regionalism from its geopolitical construction" (Jonas, 2012b: 822-823). At the same time, cross-border regions were exclusively geopolitical in their origins (Perkmann, 2003; 2007'), yet we are now seeing work examining their geoeconomic potential (Nelles and Durand, 2014). 
What cannot be underestimated is how the geopolitical and geoeconomic logic explaining the emergence of these new regional spaces also impacted the more conceptual debate. For the strongest advocates of adopting a relational approach to regions and regionalism, both capital accumulation and governance are "about exercising nodal power and aligning networks in one's own interest, rather than about exercising territorial power" (Amin, 2004: 36). However, for critics such as Jones and MacLeod (2004), the relational perspective is most convincing when dealing with cross-border economic flows, proving less convincing when considering acts of political mobilization and cultural identity which are often 'territorially articulated'. The result has been an impasse between the 'radicals', those who wished to jettison territorial-scalar approaches in favour of the relational perspective, and the 'moderates', those wishing to retain and further develop territorial-scalar approaches alongside this new relational perspective (Varró and Lagendijk, 2013). Nevertheless in recent years there have been concerted efforts to explore "a conceptual middle road" (Jones, 2009: 496). Perhaps the most significant development in this regard is Jessop et al.'s (2008) argument that the ontological privileging of any single dimension (e.g. networks) must be dispelled in favour of approaches that examine the relative significance of multiple dimensions of sociospatial relations (territory and place and scale and networks) when explaining a given sociospatial landscape.

A key facet of how this debate is developing is the desire of those involved to examine how the various dimensions of sociospatial relations (e.g. territory and network) come to be complementary, contradictory, overlapping, or competing in different configurations of state/space. Yet, one important aspect missing from the debate is our understanding of how the various types of networked regional spaces are themselves (in)compatible. Going back to our earlier example, although city-regions and cross-border 
regions have been examined in relation to territorial-scalar constructs this has been done in isolation because their starting points were rooted a geoeconomic and geopolitical logic respectively (Figure 2a). From a national perspective city-regions and cross-border regions were considered to be very different spaces geographically - the former occupying the interior, the latter exterior border areas - meaning the need to consider their complementarity was simply not necessary. However, movement in academic and policy circles to consider the geoeconomic and geopolitical significance of city-regions and crossborder regions urgently requires us to extend this analysis to reflect their potential complementarity in both theory and practice (Figure 2b). Moreover, as we will illustrate, these developments bring forward the potential for new networked regional spaces to emerge - e.g. cross-border metropolitan regions (Figure $2 c$ ). ${ }^{\text {ii }}$

Following a brief introduction to the challenge of conceptualising regions (Section 2), our paper aims to bring some clarity to these more abstract conceptual challenges by analysing the practical obstacles faced by policy elites in constructing a new relational vision of Germany's space economy in Section 3. Divided into three parts, the first part examines the original Leitbild (2006) as an example of the linear shift from a territorial planning perspective (based on the Länder) to a new networked planning framework (based on cityregions). The second part then examines the Federal State's attempts to incorporate crossborder regions - missing from the original Leitbild - alongside city-regions by invoking the idea of cross-border metropolitan regions (Figure $2 \mathrm{c}$ ). In the third and final part we reveal that while it appears possible in the abstract to combine city-regions and cross-border regions into a single, coherent configuration of networked regional space, in practice territorial-scalar politics acts as a barrier to this. 


\section{REGIONAL STUDIES - GOING BEYOND THE TERRITORIAL/RELATIONAL DIVIDE}

After a decade-long back-and-forth exchange over how best to conceptualise regions and regional space it is widely considered that ontologically-tuned either/or debates have proved to be a cul-de-sac for regional studies (Jones and Paasi, 2013). The problem, as illustrated by Paasi (2008: 265-266), is that "territorially bounded spaces have been like a red rag to a bull for many relationalists - even though relational and territorial spaces may exist concomitantly". This quote is revealing because it simultaneously captures the step change in approach to conceptualising regions and regional space. Whereas not too long ago the debate was firmly ensconced in the territorial/relational divide, today a new regional studies is emerging marked by a consistent line of argumentation - regionalism has to be understood as both relational and territorial. Some notable testimonies to this include:

"[F]rom the point of view of a relational approach, there is absolutely no conflict ... Territories are constituted and are to be conceptualized, relationally ... They exist in constant tension with each other, each contributing to the formation, and the explanation, of the other." (Massey 2011: 4)

"The conventional distinction ... misses the extent to which each necessarily defines and is defined by the other - territories are not fixed, but the outcome of overlapping and interconnecting sets of social, political, and economic relations stretching across space, while the existence of identifiable territories shapes and in some cases limits the ways in which those relations are able to develop (in other words relational space and territorial space are necessarily entangled)." (Cochrane and Ward, 2012: 7)

"Progress on the regionalism question will require further examination both of the relational thinking about territorial politics and of territorial thinking about relational processes." (Jonas, 2012a: 270)

Nevertheless, what these quotes also illustrate is that much of the focus hitherto has been on examining the extent to which territoriality and relationality are complementary 
alternatives, rather than on the ways in which different networked regional spaces are themselves complementary alternatives. This is significant for two reasons. First, a 'relational approach' to understanding regions cannot be considered internally coherent. Ever since Doreen Massey (1979) exposed concerns that the UK's 'regional problem' increasing spatial inequalities between regions - could only be tackled if regional policy addressed the 'relations' producing these inequalities, a tradition of political economy analysis seeks to understand regions by the social relations characterising them in a given instance (Markusen, 1983; Jones and MacLeod, 2004; Jones, 2009). Philosophically aligned to (critical) realism this standpoint is adopted by 'moderate' relationalists, and opposed by the 'radicals' who, drawing on post-structuralist understandings of relationality, argue that regions and regional space can only be understood in relational terms (Varró and Lagendijk, 2013). Meanwhile and despite this, second, there remains this inbuilt tendency to compare territoriality with relationality in singular ways - a point usefully reinforced by the quotes above. Although this is a somewhat inevitable legacy of the ontologically-tuned either/or debate of previous regional studies, in a world of ever more complex regional configurations there are clear limitations of treating territoriality and relationality in a purely singular way. Our argument is simple: further examination of ever more complex regional configurations means it is no longer going to be acceptable to talk about territorial and relational processes, approaches, and spaces without recognising their plurality.

2.1 The challenge of conceptualising ever more complex configurations of regional spaces

Nowhere has the challenge for conceptualising ever more complex spatial configurations been more starkly exemplified than in Jessop et al.'s (2008) Territory-Place-Scale-Network 
(TPSN) framework. Exasperated at the constant ontological privileging of single dimensions of sociospatial relations (territory or place or scale or network) - in particular, that following a given 'spatial turn' this single dimension is assumed to possess some exclusive explanatory power and predictive value - the TPSN framework signalled Jessop et al.'s attempt to analyse how the different dimensions of sociospatial relations (territory and/or place and/or scale and/or network) fuse in different ways, at different times, and in different contexts to secure the overall coherence of capitalist, and other, social formations. Founded on the authors belief that new conceptual frameworks are required to theorize the inherently polymorphic and multidimensional character of sociospatial relations, the TPSN framework is being regarded as a watershed moment for theorising sociospatial relations and a significant forward step conceptually.

If the reorientation of regional studies from territoriality or relationality, towards territoriality and relationality, and now polymorphy amounts to a conceptual leap forward, then methodological and empirical advances have been more considered, incremental and circumspect. Deploying the language of Aesop's fable and classic children's story, 'The Tortoise and the Hare', in the quest to consider the inherently polymorphic and multidimensional character of sociospatial relations the conceptual hare has raced far ahead of the empirical tortoise - a fact not lost on the original authors. In making their conceptual leap forward Jessop et al. (2008: 396) recognise that this needs to be matched by "debate on what methodological strategies might be appropriate for investigating the polymorphy of sociospatial relations". Indeed two of the authors have attempted, subsequent to this, to examine strategies for investigating polymorphy in sociospatiality through their own research into state spatial projects relating to European state formation and city-regional development strategies (Jones and Jessop, 2010). 
The empirical challenge has also been recognised and taken up by others. Cochrane and Ward (2012: 7), for instance, seek to go beyond the territorial/relational divide in understanding policymaking when making the argument that increasingly "what matters is to be able to explore the ways in which the working through of the tension serves to produce policies and places, and policies in place" - because as Peck and Theodore (2010: 171) observe:

"If processes of policy mobilization have indeed become increasingly transnational in reach and cross-scalar in constitution, if they are manifest in ever more complex relational combinations, then there is an inescapable need to confront new methodological challenges. Spatially demarcated forms of policy evaluation certainly will not do. New methodological strategies must be developed to expose and critically interrogate the interconnectedness of policy regimes between places and across scales."

Cochrane and Ward (2012) thus ask researchers to 'think differently' about public policy and its formation in place. This has clear parallels and overlaps with developments in regional studies where Europe is providing an important context for researchers wishing to examine territorial, place-related, scalar and networked dimensions of regional formation and transformation. It is also the context in which our paper has been developed.

The attraction of Europe is derived from a number of interrelated developments which have been pervasive across European space since the 1980s: (i) the widespread abandonment of traditional Keynesian models of spatial redistribution in favour of competitiveness-oriented state spatial strategies designed to enable major urban regions to be particularly attractive to transnational capital; (ii) the rise of cross-border geopolitical cooperation; (iii) the making of a distinctly European Spatial Development Perspective; (iv) the new spatial thinking around the emergence of overlapping and flexible 'soft spaces' of 
governance and planning, leading to the so-called 'Europeanisation' of spatial planning with all its relational inflections; and $(v)$ the reorientation in characterisation of European spatiality from a 'Europe of bounded regions' towards a 'Europe of unbounded regions'. What we arrive at is a situation where these interrelated developments are seen as part of a bigger political agenda, where the aim is for a 'Europe without borders' (Faludi, 2013a). With its emphasis on relational thinking this represents a real challenge to territorial approaches and is forcing researchers to undertake a critical review of the 'territorialism underlying' EU treaties (Faludi, 2013b).

Of course, the faltering nature of the nationally configured Fordist-Keynesian model has encouraged the proliferation of competing regional imaginaries (and other spatial imaginaries) in a process akin to letting a thousand flowers bloom. The result, as Jessop (2012: 11-12) usefully articulates, is that when we reflect on these developments

“... we can see that a region can be imagined and constructed in many ways and that there is considerable scope for competing regional imaginaries and different kinds of region-building - from tightly sealed territories to porous nodes in a networked space of flows."

Focusing on the spatial aspect of regional imaginaries, what has sometimes been overlooked in these debates is the temporal aspect. Here we are particularly drawn towards Anssi Paasi's work, and his recognition of the need to distinguish between 'dominant', 'newly dominant', and 'residual' approaches to region-building (Paasi, 2008). Derived from this, understanding the complex interaction between competing regional imaginaries requires us not only to be asking which regional spaces are dominant, newly dominant, or residual in a given instance, but how and why this be so. This is critical to our understanding because "it is never the spatial form that acts, but rather social actors who, embedded in 
particular (multidimensional) spatial forms and making use of particular (multidimensional) spatial forms, act" (Mayer, 2008: 416). Therefore, underpinning the formation, continued existence and perpetual transformation, even potential disappearance of regions and regional space are questions of agency (who is involved), process (how are they involved), and specific interests (why are they involved).

In this way Europe has been a focal point for researchers identifying in which spacetimes territorial and relational processes (and spaces) are (in)compatible. Europe is also the backdrop for new intellectual debates and practical developments, including, if and when territoriality and relationality appear incompatible examining how actors have attempted to reconfigure them as complementary alternatives (Mayer, 2008). This can include gradually formalizing new regional spaces to facilitate "stabilization" of what are often fragile, informal or semiformal nonstatutory spatialities when they first emerge (Metzger and Schmitt, 2012). It also includes conceptual switching where actors use different constructions of the regional concept (as place, as space, as territory, as scale, as network) to align new regional spaces to extant structures of state scalar organisation (Harrison, 2013). What this work alerts us to is how - contrary earlier notions of a "relationally imagined regionalism that is freed from the constraints of territorial jurisdiction" (Amin, 2004: 42) - the role of the nation-state and its extant territorial politics in shaping contemporary region building cannot be underestimated (Jonas, 2012a).

Nevertheless, our argument is that for all this work has done to advance understandings of the space-times territoriality and relationality are complementary alternatives, there has been no meaningful debate about the space-times in which different networked regional spaces are (in)compatible. The tendency to relate each networked regional imaginary to territory-scale is not surprising given the enduring legacy of 
institutional forms of Fordist-Keynesian state spatial organisation. Nonetheless, we wish to extend the analytical gaze beyond this singular territoriality/relationality binary to investigate the plurality of relationally-configured regional spaces, examining their complementarity to one another as well as to territory-scale. To help us do this we focus on Europe, where the interaction between border and metropolis is being brought increasingly to the fore by a European regional policy captivated by the geoeconomic logic for promoting the competitiveness of city-regions, alongside a European agenda committed to integration and cohesion aimed at reducing the national borders of its member states to 'mere administrative boundaries' (Association of European Border Regions, 2008: 15 quoted in Nelles and Durand, 2014: 107). Specifically we focus on developments in Germany where the framing of a new spatial development discourse around metropolitan regions is presenting policy elites with the challenge of making different networked regional spaces complementary as well as with territory-scale.

Methodologically, our paper explores these issues by analysing the evolving cartographic representation of Germany's space economy. Our interpretation of these spatial maps is inspired by the work of Jensen and Richardson, who, when considering the contested representation of European space (mentioned above) revealed that:

"whilst iconic representations of European space articulate an apparently unified vision of European spatial development, of a 'Europe of flows', they also reproduce the major uncertainties, conflicts and unresolved tensions at the heart of the spatial development strategy. These tensions centre on competing configurations of urban and regional development and mobility" (2003: 10, our emphasis)

Complemented by actor-related reflections, what the time-series of 5 maps produced in the period between Leitbild 2006 (original) and Leitbild 2014 (revised) allow us to do is extend 
the traditionally space-dominated approach - which involves analysing a single image or images of the same spatial development by different actors - to problematising the powerful role of cartography in reproducing policy discourses of (regional) space, by adding a new layer of analytical exploration accounting for how a single spatial vision evolves over time.

\section{GERMANY'S LEITBILD: IN WHAT SENSE A ‘EUROPE WITHOUT BORDERS’?}

For much of the twentieth century the principles for spatial planning in Germany were underpinned by the Federal Government's commitment to promoting balanced economic growth and equal living conditions through financial equalization (Länderfinanzausgleich). A classic tool of spatial Keynesianism, federal laws on spatial planning were interpreted by planners as disincentivising further accumulation of resources in major cities to enable additional resources to be directed towards underdeveloped rural and border zones. That was until the late-1980s/early-1990s when the aggrandizement of globalization forces and processes of European integration provided a new principle and stimulus for the regionalisation of spatial planning. Undergirded by 'new regionalist' thinking, the Federal Government largely abandoned the traditional Keynesian model of spatial redistribution to begin incentivising the accumulation of resources in metropolitan areas through more competitiveness-oriented state spatial strategies sii. $^{\mathrm{ii}}$

One of the most important state strategies saw the Federal Government confer 'European Metropolitan Region' (EMR) status upon eleven areas between 1995 and 2005. The initial six (Berlin/Brandenburg, Hamburg, Munich, Rhine-Main, Rhine-Ruhr and Stuttgart) were identified for their 'superior' strategic importance to national and international competitiveness (Bundesministerium für Raumordnung and Bauwesen und Städtebau 
[BmBau], 1995). Thereafter a further five (Halle-Leipzig-Sachsendreieck (newly named Mitteldeutschland), Bremen-Oldenburg, Hanover-Braunschweig-Göttingen-Wolfsburg, Nuremberg, and Rhine-Neckar) were added, albeit possessing fewer economic functions. Alongside this a "Metropolitan Regions Initiative" (Initiativkreis Europäische Metropolregionen, hereafter IKM]) group formed in 2001 to manage relations between the 11 EMR and, as this strategy paper attests, lobby federal ministers to (continue to) recognise the unique contribution of metropolitan regions when considering future developments to the approach:

"Metropolitan regions are characterised by special features which distinguish them from other conurbations ... it is indispensable that the German metropolitan regions measures themselves against other metropolitan regions at home and abroad." (IKM, 2003: 12)

Following on from this, in 2006 the Federal Government and federal state ministers responsible for spatial planning (Landesplanung) established new spatial development models and guidelines for cities and regions. Outlined in 'Concepts and Strategies for Spatial Development in Germany' (Leitbilder und Handlungsstrategien für die Raumentwickung in Deutschland, hereafter Leitbilder) metropolitan regions became the centrepiece for the first of three guiding principles - on 'growth and innovation' (Bundesministerium für Verkehr Bau- und Stadtentwicklung/Bundesamt für Bauwesen und Raumordnung [BMVBS/BBR], 2006). Nevertheless, Hesse and Leick (2013: 343) argue that although Leitbild 2006 came to represent a 'necessary adjustment' of planning policy to changing conditions, the discursive framing was "theoretically contradictory, empirically vague and conceptually fragile". What they point to is the reorientation of the EMR discourse away from the relatively consistent and coherent singular geoeconomic logic used to select the first 6 EMR towards a new 
plurality of 'metropolitan' regional spaces aimed at stabilising the new spatial development model through political consensus (Harrison and Growe, 2014). Leitbild 2006 arguably represented the first stage in the federal state's envisioning of Germany within a 'Europe without borders' also.

\subsection{Stage 1: A Europe with (national) and without (intranational) borders?}

Representing Germany as a non-territorial, relationally-networked space economy, the most striking feature of Leitbild 2006 is how traditional concepts of regional space (Germany's Länder) are jettisoned (Figure 3). What is also striking is how Leitbild 2006 reaffirms this important distinction in starting points for new relationally networked regional spaces between a geoeconomic 'city-regional' vision (Figure 3) and a geopolitical 'cross-border' vision (Deas and Lord, 2006: 1852). Yet more significant than either of these observations is to recognise that Figure 3 is the federal state's response to internal and external political pressures: internally, to recommit to the national principle of equalised living conditions and balanced economic growth; externally, to promote the superior strategic importance of metropolitan regions internationally. That the internal goal of regionalism is to be achieved through financial equalization between territorial regional spaces (Länder) while the external goal is to be achieved through networked regional spaces means Leitbild 2006 is, in effect, the lower section of Figure $2 a$ in practice. The challenge this posed was very clear to actors in the Federal Ministry of Transport, Building and Urban Development responsible for spatial planning:

"The concept of metropolitan regions in Germany is a success story of spatial planning. [...] A series of German city-regions ... has realised that it's necessary to find a position within European competition and to focus regional powers beyond local borders. [...] In the long-term this should result in the development of self- 
organised regional communities of responsibility, not replacing the existing administrative spatial structures of Federal States and regions but reasonably complementing them." (Staats, 2005: 1, our emphasis)

What Figure 3 reveals is how the federal state favoured a more 'versatile interpretation' of metropolitan regions (Hesse and Leick, 2013) able to "relate to all types of area - from ruralperipheral to metropolitan areas" (Tiefensee and Pfister, quoted in BMVBS/BBR, 2006: 5). The result is not one type of networked regional space but a plurality of networked regional spaces each underpinned by its own logic, enabling the federal state to achieve (in theory at least) a different political aspiration, and hierarchically differentiated from the other. Most obvious are the 'metropolitan regions'. Reinforcing their superior strategic importance, metropolitan regions remain, as does their political construction according to a spatiallyselective, city-first, agglomeration perspective. Alongside this, 'large-scale areas of responsibility' are identified for the first time. Each comprises a metropolitan region and its wider 'area of influence'. A move to include those areas previously on the fringes of, or excluded from, the metropolitan region discourse within 'large-scale areas of responsibility' serves to reorient metropolitan regionalism from spatially-selectivity towards spatiallyinclusivity. Nevertheless, achieving spatial inclusivity raises a new political concern.

Reconfiguring Germany's space economy along relational lines cultivates new bordering processes, determined not by political, administrative and territorial boundaries but by the fuzzier boundaries of metropolitan form and function. The potential for reigniting time-honoured debates over place-based competition, both within and between metropolitan regions, was undeniable so the federal state set about alleviating some of this concern by emphasising the formation of a multi-nodal inter-urban network extending across all geographic space: 
"We have the vision of 'joint responsibility' of metropolitan core and their peripheries. The metropolises must see themselves as nodes of regional networks achieving their goals only in cooperation with the partners of their rural suburban areas." (Staats, 2005)

Part and parcel of this is the move to recognise 'growth regions outside Metropolitan Regions'. These are places such as market towns and tourist hotspots which would ordinarily be excluded from this policy because they lack an urban core but are increasingly recognised for the multi-functional role they fulfil as prime locations for retail, service, administrative, tourist, leisure and cultural purposes (Scott, 2012).

What we take from this is how despite erasing territorial regional spaces from the 2006 map policy elites could not simply ignore territory and territorial politics. Perhaps the clearest indication of this is the extent to which the national border remains visible reminding us that the regionalism question is as much about state territoriality and territorial politics as it is discourses of globalized economic competitiveness (Jonas, 2012a). Leitbild 2006 also provides confirmation that from a national perspective interior cityregions and exterior cross-border regions were considered mutually exclusive. In fact, for all Leitbild 2006 testified to this relationally-inspired trend of actors constructing new, increasingly networked, diffuse, and flexible, forms of planning and governance arrangements that "stretch across and beyond given regional boundaries" (Allen and Cochrane, 2007: 1163), when that interior regional boundary was also the exterior national boundary the separation of city-region and cross-border region was very much evident.

Perhaps unsurprisingly, the strongest reactions against Germany's new spatial development model came from rural areas and border regions. Critics and lobbyists argued that some growth areas outside metropolitan regions could easily measure up to the 
requirements for EMR status were they judged on metropolitan functions that stretch across and beyond the German border - a fact not lost on the federal state ministers responsible for spatial planning:

"The specification and partial reorientation of the Leitbilder to 'strengthen competitiveness', 'secure services for the public', and 'regulating land use' should recognise future spatial development issues. These include [...] cross-border and pan-European ties." (Ministerkonferenz für Raumordnung, 2013b: 1)

What we arrive at is an important juncture in the evolution of Germany's new spatial development model. Responding to the political pressure exerted by rural areas and crossborder regions, the federal state established 7 model regions for 'supraregional partnerships' (Überregionale Partnerschaften) and 4 model regions for 'supraregional partnerships in cross-border interconnected areas' (Überregionale Partnerschaften in grenzüberschreitenden Verflechtungsräumen) in 2007-8. More significantly, what we see upon completion of the demonstration projects of spatial planning (MORO) in 2011 is how the outcome of this politically-driven discussion is to overlay the geoeconomic vision of Leitbild 2006 with a layer of potential geopolitical institutional spaces (Figure 4). It is, in effect, Figure $2 b$ in practice (though critically without the connecting line between crossborder region and city-region in all but one case - the Lake Constance region). Nevertheless, in taking this forward, internal discussions led by political actors within the regions resulted in the production of a new series of maps attempting to make cross-border regions and cityregions compatible within a single, coherent vision based on networked regional spaces.

Prominent in the discussions was the "Metropolitan Border Regions Initiative Group" (Initiativkreis Metropolitane Grenzregionen, hereafter IMeG), established in 2011 at the completion of the first MORO. Supported by the Federal Ministry (BMVBS), the IMeG 
represents the 4 cross-border regions in much the same way as the IKM lobbies for the 11 EMR. The participation of IMeG in the discussions over the new Leitbild is important because they have one, unequivocal, aim:

"The IMeG emphatically demands that these regions be included in the federal concepts." (IMeG, 2012: 7)

But unlike the IKM, who promote exceptionalism, the IMeG choose to emphasise their role as complementary alternatives to EMR:

"IMeG shares the aim of the metropolitan regions in German ... The IMeG is no substitute for existing institutions, but rather aims at an effective and synergetic collaboration with existing cooperation structures and networks on a national and European level." (ibid.)

\subsection{Stage 2: Towards a Europe without (national and intranational) borders?}

In 2012, two internal drafts for a new version of the Leitbild were produced (Figure $5 \& 6$ ). These formed the basis for internal discussion between political actors within the regions but also at public meetings. The most significant elaboration in the new visions was the newly dominant geopolitical perspective. This took two forms. First, the meaning attached to 'metropolitan' changed. In 2006, the Leitbild differentiated between 'dense' metropolitan areas and 'extended' metropolitan areas. By 2012, this differentiation was replaced by a single category of metropolitan area, one which for the first time was not rooted in the geoeconomic logic of metropolitan-scaled agglomerations but reflected geopolitical cooperation areas. In addition, the zones of transition between the functionally-connected metropolitan areas are removed in favour of more definitive political borders delimiting cooperation areas. Places are no longer identified as being included or on the fringes of 
inclusion, but are either included or excluded. One consequence of this is the rather interesting changes made to the representation of metropolitan spaces in Germany. The most distinct example is the comparison between Rhine-Ruhr, which now appears slightly smaller in size, and Berlin-Brandenburg and Mitteldeutschland, which have both been enlarged significantly.

Second, the meaning attached to 'networks' changes. In 2006, networks referred to virtual flows and circulation (of knowledge, ideas, and capital) and were represented through the 'hub and spokes' model for conceptualising city-regions. By 2012, virtual flows had all but disappeared (only remaining to acknowledge functional economic areas which do not have a metropolitan core) to be replaced by absolute flows (of people and material goods). National and European infrastructure (rail, road, airport, seaport) is now superimposed on to the original Leitbild. At one level, this serves to interconnect cores located beyond Germany - a significant development as Leitbild 2006 only connected those cores (predominantly to the west) which subsequently formed the 4 cross-border model regions. At another level, it took the Leitbild from its original guise, as an abstract vision of Germany's space economy, towards a more traditional spatial planning framework. What we are witnessing is the hardening of a previously 'soft' spatial vision through a process of gradual formalization (cf. Metzger and Schmitt, 2012).

Illustrating the extent to which politics came to the fore in these new visions, we also observe how the national border is emphasised not only on land but also at sea where the state has planning competencies at the federal level and through the Länder which border the sea. Moving forward, the next stage saw political actors begin to consider the idea of recognising cross-border metropolitan regions, specifically how they might interface with city-regions and cross-border regions (cf. Figure $2 \mathrm{c}$ ). 


\subsubsection{Moving towards a 'Europe without borders'?}

Leitbild - Draft $1 a$ is the first (intermediate) step towards the federal state's vision of a 'Europe without borders' (Figure 5). The result is a two-tier structure for relationallynetworked regional spaces: the eleven metropolitan regions retain their primary status as areas of 'superior' importance, but four cross-border metropolitan regions are added. Critically, the aspiring cross-border metropolitan regions are clearly differentiated from interior metropolitan regions, emphasising that for federal ministers they remained qualitatively different types of networked regional space at this time.

\subsubsection{Arriving at a 'Europe without borders'?}

Leitbild - Draft $1 b$ is the second (and final) step towards the federal state's vision of a 'Europe without borders' (Figure 6). The result is a single-tier of relationally-networked regional spaces that incorporates cross-border regions and interior city-regions. All fifteen are now considered metropolitan regions of 'superior' importance. Alongside this, the two institutional bodies responsible for advancing the claims for each type of networked regional space are aligned in the key. But there are also further extensions to the vision. With the aim of aligning the twin goals of competitiveness and territorial cohesion (in a European context) and territorial equilibrium (in the German context), the first extension sees the federal state ensure all places are included within the vision. Those areas within Germany which are not included in Leitbild - Draft $1 a$ are now included with the title 'sustainable growth' (nachhaltiges Wachstum) areas, an acknowledgement to their (small) contribution to national growth. By virtue of creating a single-tier of relationally-networked regional spaces that incorporates cross-border regions and interior city-regions, the second 
extension is the softening of the national border in those areas to the south and west where cross-border metropolitan regions are identified.

In view of this, considering Leitbild - Draft $1 a$ and $1 b$ together could be argued to reveal how constructing a single-tier from different relationally-networked regional spaces which are subnational in scale pertains (in theory) to a more borderless, more inclusive spatial politics.

\subsection{Stage 3: A 'Europe with (national) and without (intranational) borders'}

In April 2013, the final draft of the Leitbild was produced (Figure 7). This formed the basis for a public consultation prior to the expected publication of Leitbild version 2.0 in 2014 . The most significant development is the federal state's retreat to a vision of a 'Europe with (national) and without (intranational) borders'. Bound up with this are the strong geoeconomic focus from Leitbild 2006 and the stronger geopolitical focus of Leitbild - Drafts $1 a$ and $1 b$. This is reflected in the following ways. First, there is a return to the original differentiation whereby 'metropolitan' was categorised as either dense metropolitan areas (agglomerations) or extended metropolitan areas (political co-operations). Alongside this, transition zones return to remove the more definitive political borders delimiting cooperation areas, thus ensuring places are identified as being included or on the fringes of inclusion, rather than included or excluded. As a consequence of this, the 'sustainable growth' areas identified in Leitbild - Draft $1 b$ are no longer deemed necessary.

Second, when looking at the metropolitan areas within Germany, the single-tier of relationally-networked regional spaces appears to be retained. Those areas which are part of the four cross-border metropolitan regions located within Germany appear to be awarded equal status (highlighted by the use of the same colour - blue). At one level, 
positioning Germany in its European context actually reveals an implicit two-tier structure. Unlike Leitbild - Draft $1 b$, where the softened border in the south and west could be seen to suggest a capacity for political power to extend beyond the national border, there is a clear recognition that the federal state has no jurisdiction to intervene in planning beyond the national border (reflected in the use of a different colour - light grey). At another level, the definition of cores also implies a two-tier structure. Here the cores of city-regions are marked in a different colour (black) to cores of cross-border metropolitan regions (blue). ${ }^{\text {iv }}$

Third, absolute flows that constitute networks remain from Leitbild - Drafts $1 a$ and $1 b$ but there is now a further confirmation of the geopolitical significance of the state. This is significant because "the growth of city-regions is, more often than not, associated with new demands on the state, not least for the collective provision of strategic social and physical infrastructures" (Jonas, 2013: 284-285). In Germany, the growth of city-regions has placed new demands on the federal state to focus on national infrastructure issues and ensure Germany strengthens its strategic position within Trans-European Transport Networks (TENT) (Ministerkonferenz für Raumordnung, 2013a). This can be seen in the new map, where the majority of infrastructure sites located beyond the dense metropolitan areas - both within and beyond Germany - disappear, while more infrastructure appears within the dense metropolitan areas (e.g. airports in Leipzig and Bremen). Again this reflects the federal state's focus on the distinct geoeconomic importance of metropolitan cores. Meanwhile, and as direct result of this, absent is the abstract vision of virtual flows from Leitbild 2006. With it a new title for the Leitbild ('Strengthening competitiveness'; Wettbewerbsfähigkeit stärken) also suggests the prominence afforded to innovation in Leitbild 2006 has been weakened. This change is significant because once more it reflects a negotiated response by the federal state to internal and external political pressures: 
internally, to the concerns of many of the actors participating in the discussion meetings that the Leitbild should not associate knowledge production only with metropolitan-scaled agglomerations; externally, to be more strongly oriented towards the Territorial Agenda of the European Union (TAEU) and its Europe 2020 initiative.

Finally, the Lake Constance region does not have a dense metropolitan area yet retains its status as a 'cross-border metropolitan region'. A legacy of being a MORO political co-operation area (2008-2010) this decision is rooted in the longer tradition these four cross-border regions have within federal discussions. There are ten other cross-border regions officially recognised in INTERREG IV-A which are currently excluded from the Leitbild vision (Bundesinstitut für Bau-, Stadt- und Raumforschung [BBSR], 2012). Perhaps the clearest indication of the political nature of the Leitbild exercise is the potential for including those cross-border regions located beyond the national border but who did not participate in the MORO - a scenario currently being discussed by political actors:

"What is happening on the western border has a long tradition; on the eastern borders, it is much newer and needs to be tested."

Katharina Erdmenger, Head of Division, European Spatial Development and Territorial Cohesion, BMVBS (quoted in IMeG, 2013: 24)

\section{CONCLUSION: ONE MORE STEP ALONG THE REGIONAL WORLD WE GO}

This paper has sought to develop an extended approach to going beyond the territorial/relational divide, namely, by recognising the plurality of networked regional spaces operating at different scales and according to different spatial logics. In contrast to previous work examining the emergence of new, generally more networked, flexible, and loosely bound, regional spaces, this paper suggests that considering the extent to which single networked regional spaces are complementary with territory-scale is not sufficient in 
a world comprising increasing numbers of competing regional imaginaries. Our starting point was the recognition that although city-regions and cross-border regions - as networked regional spaces - have previously been considered separately in relation to territory-scale (Figure 2a), there is increasingly a need to consider their own complementarity alongside territory-scale (Figure 2b). Indeed, this is becoming more important following movement on the part of researchers and policy elites to consider the geopolitics of city-regionalism and the geoeconomics of cross-border regions. What these developments also bring forward is the potential for new networked regional spaces to emerge (Figure 2c).

Thinking about regions in these terms helps highlight a range of issues about how regionalism evolves both in theory and practice. The first is the inherently complex and messy landscape of competing regional imaginaries, spaces, projects and strategies we are now faced with - a situation recently captured by Jessop (2012: 26):

\footnotetext{
"The overall configuration of regions within the world market cannot be planned with any certainty of success. On the contrary, given that there are many competing regional imaginaries (as well as other spatial or spatially-attuned imaginaries), the configuration is the unintended, unanticipated, and, indeed, 'messy' result of the pursuit of numerous regional projects in conjunctures that cannot be grasped in all their complexity in real time."
}

What this brings us back to is a question first posed by Paasi (2008) in response to the publication of Jessop et al.'s (2008) TPSN framework, namely, 'is the world more complex than our theories of it?' Certainly our analysis points toward ever more complex configurations of regional space being deployed as actors attempt to secure the overall coherence of capitalist, and other social, formations. Such struggles are commonly a response to new expressions of region-building, underpinned in many cases by a relatively 
consistent and coherent singular logic. Where complexity arises is when these new regional formations encounter other regional imaginaries, be they territorial, place-related, scalar or networked. It is these encounters with other regional imaginaries which are crucial for understanding the constitution of complex multidimensional spatialities.

Ever more complex configurations result from the challenge of making these different regional imaginaries complementary. The problem is these configurations are only ever temporary. Actors face the perpetual challenge of finding new ways to overcome the instability arising from emergent processes of regional (trans)formation contradicting, competing, or overlapping with other forms of sociospatial organisation. In this paper we have shown how this challenge triggers the political construction of new regional spaces, each underpinned by a different logic and deployed to serve a specific political aim. The result is a distinctly new 'regional problem'. To make networked regional spaces complementary with other regional spaces (networked or territorial-scalar) requires an increase in the number and type of regional spaces; this results in ever more complex configurations of regions; and although purportedly necessary for stabilising one regional configuration actually serves to perpetuate the creation of even more competing regional imaginaries which then in turn need stabilising through the creation of new regional spaces and configurations.

Second, there is a wider political significance to our analysis. Alongside their importance to the spatial configuration of state/space, cross-border metropolitan regions represent 'Europe in miniature'. Closer interaction between 'border' and 'metropolis' in the formation of cross-border metropolitan regions is significant because it is providing a unique lens through which to evaluate the successes and/or failings of the European regional project. What our paper points to is the geopolitical goal of European integration and the 
geoeconomic goal of European competitiveness starting out according to different logics, developing distinct narratives, and focusing on markedly different types of networked regional space. Our analysis of the political construction of Germany's Leitbild from 20062013 reveals not only which regional spaces are emergent, dominant, residual but by incorporating understandings of how and why they emerge, dominate, recede over this period we are able to provide new insights into the contested nature of the European project and the notion of a 'Europe without borders'. This suggests that for all cross-border metropolitan regions are recognised as new and important types of networked regional space, they also identify a wider regional problem which is the requirement for ever more complex configurations of regions to stabilise the overall coherence of capitalist, and other social, formations. 
ACKNOWLEDGEMENTS

(Removed for refereeing) 


\section{REFERENCES}

Agnew J, 2013, “Arguing with regions" Regional Studies 47 6-13

Allen J, Cochrane A, 2007, "Beyond the territorial fix: regional assemblages, politics and power" Regional Studies 41 1161-1175

Amin A, 2004, "Regions unbound: towards a new politics of place" Geografiska Annaler 86B $33-44$

Anderson J, O'Dowd L, 1999, “Borders, border regions and territoriality: contradictory meanings, changing significance" Regional Studies 33 593-604

Association of European Border Regions (AEBR), 2008, Cooperation between European Border Regions: Review and Perspectives (NOMOS: Baden-Baden)

Bundesinstitut für Bau-, Stadt- und Raumforschung (BBSR), 2012, Raumordnungsbericht 2011 (BBSR: Bonn)

Bundesministerium für Raumordnung and Bauwesen und Städtebau (BmBau) (1995) Raumordnungspolitischer Handlungsrahmen - Beschluss der Ministerkonferenz für Raumordnung in Düsseldorf am 8 März (BmBau: Bonn)

Bundesministerium für Verkehr Bau- und Stadtentwicklung/Bundesamt für Bauwesen und Raumordnung (BMVBS/BBR), 2006, Leitbilder und Handlungsstrategien für die Raumentwicklung in Deutschland (BMVBS/BBR: Berlin)

Castells M, 1996, The Rise of the Network Society (Blackwell: Oxford)

Cochrane A, Ward K, 2012, "Researching the geographies of policy mobility: confronting the methodological challenges" Environment and Planning A 44 5-12

Deas I, Lord A, 2006, "From a new regionalism to an unusual regionalism? The emergence of non-standard regional spaces and lessons for the territorial reorganisation of the state" Urban Studies 43 1847-1877. 
Faludi A, 2013a, "Territorial cohesion, territorialism, territoriality, and soft planning: a critical review" Environment and Planning A 45 1302-1317

Faludi A, 2013b, "Territorial cohesion and subsidiarity under the European Union treaties: a critique of the 'territorialism' underlying" Regional Studies 47 1594-1606

Harrison J, 2013, "Configuring the new 'regional world': on being caught between territory and networks" Regional Studies 47 55-74

Harrison J, Growe A, 2014, “From places to flows: planning for the new 'regional world' in Germany" European Urban and Regional Studies 21 21-41

Harrison J, Hoyler M, 2013, "Governing the new metropolis" Urban Studies online early DOI: DOI: $10.1177 / 0042098013500699$

Hesse M, Leick A, 2013, “Growth, innovation, metropolitan regions: reconstructing the recent modernisation of spatial development guidelines in Germany" Raumforschung und Raumordnung 71 343-359

Initiativkreis Europäische Metropolregionen (IKM), 2003, Strategiepapier (Technische Universität, Berlin)

Initiativkreis Metropolitane Grenzregionen (IMeG), 2013, Initiative Group of German Regions in Cross-Border Functional Regions - Final Report (IMeG, Saarbrücken)

Jensen OB, Richardson T, 2003, "Being on the map: the new iconographies of power over European space" International Planning Studies 8 9-34

Jessop B, 2012, "Cultural political economy, spatial imaginaries, regional economic dynamics" CPERC Working Paper [English language version of a paper to appear in German in Brand O, P Eser, S Dörhöfer Eds 2013 Ambivalenzen regionaler Kulturen und Identitäten (Westfälisches Dampfboot: Münster)], Lancaster University, 
http://www.lancaster.ac.uk/cperc/docs/Jessop\%20CPERC\%20Working\%20Paper\%20 2012-02.pdf

Jessop B, Brenner N, Jones M, 2008, "Theorizing sociospatial relations" Environment and Planning D 26 389-401

Jonas AEG, 2012a, "Region and place: regionalism in question" Progress in Human Geography 36 263-272

Jonas AEG, 2012b, "City-regionalism: questions of distribution and politics" Progress in Human Geography 36 822-829

Jonas AEG, 2013, "City-regionalism as a contingent 'geopolitics of capitalism'” Geopolitics 18 284-298

Jonas AEG and Ward K, 2007, "Introduction to a debate on city-regions: new geographies of governance, democracy and social reproduction" International Journal of Urban and Regional Research 31 169-178

Jones M, 2009, "Phase space: geography, relational thinking, and beyond" Progress in Human Geography 33 487-506

Jones M, Jessop B, 2010, "Thinking state/space incompossibly" Antipode 42 1119-1149

Jones M, MacLeod G, 2004, "Regional spaces, spaces of regionalism: territory, insurgent politics, and the English question" Transactions of the Institute of British Geographers 29 433-452

Jones M, Paasi A, 2013, "Regional world(s): advancing the geography of regions" Regional Studies 47 1-5

Lefebvre H, 1991, The Production of Space (Blackwell, Oxford) 
Lagendijk A, 2005, "Regionalization in Europe. Stories, institutions and boundaries", in B/ordering Space Eds H van Houtum, O Kramsch, W Zierhofer (Ashgate, Aldershot) pp 77-92

Markusen A, 1983, "Regions and regionalism", in Regional Analysis and the New International Division of Labor - Application of a Political Economic Approach Eds F Moulaert, P Salinas (Kluwer Nijhoff, Boston) pp 33-55

Massey D, 1979, “In what sense a 'regional problem'?” Regional Studies 13 233-243

Massey D, 2011, "A counterhegemonic relationality of place", in Mobile Urbanism: Cities and Policymaking in the Global Age Eds E McCann, K Ward (University of Minnesota Press: Minneapolis) pp 1-14

Metzger J, Schmitt P, 2012, "When soft spaces harden: the EU strategy for the Baltic Sea Region" Environment and Planning A 44 263-280

Ministerkonferenz für Raumordnung (MKRO) (2013a) Draft Leitbilder and Action Strategies for Spatial Development in Germany (18 April) (BMVBS: Berlin)

Ministerkonferenz für Raumordnung (MKRO) (2013b), Resolution Draft - Advancing Leitbilder and Action Strategies for Spatial Development in Germany (3 June) (BMVBS: Berlin)

Nelles J, Durand F, 2014, "Political rescaling and metropolitan governance in cross-border regions: comparing the cross-border metropolitan areas of Lille and Luxembourg" European Urban and Regional Studies 21 104-122

Paasi A, 2008, "Comments on 'Theorizing socio-spatial relations'” Environment and Planning D $26402-404$

Peck J, Theodore N, 2010, “Mobilizing policy: models, methods, and mutations" Geoforum 41 169-174. 
Perkmann M, 2003, "Cross-border regions in Europe: significance and drivers of regional cross-border co-operation" European Urban and Regional Studies 10 153-171

Perkmann M, 2007, "Construction of new territorial scales: a framework and case study of the EUREGIO cross-border region" Regional Studies 41 253-266

Scott AJ, 2001, "Globalization and the rise of city-regions" European Planning Studies 9 813826

Scott AJ, 2012, A World in Emergence - Cities and Regions in the $21^{\text {st }}$ Century (Edward Elgar: Cheltenham)

Staats J-U, 2005, "Challenges for Central and Eastern European Metropolitan Regions", 4 November, http://alt.irs-net.de/download/041105Staats.pdf

Taylor PJ, Derudder B, Hoyler M, Ni P, 2013, “New regional geographies of the world as practised by leading advanced producer service firms in 2010" Transactions of the Institute of British Geographers 38 497-511

Varró K, Lagendijk A, 2013, “Conceptualizing the region - in what sense relational?" Regional Studies 47 18-28 
Figure 1: A framework for conceptualising networked regional spaces

\begin{tabular}{|l|l|l|}
\hline & Geoeconomic & Geopolitical \\
\hline Supranational (in scale) & $\begin{array}{l}\text { World city network/world } \\
\text { regions (e.g. Taylor et al., } \\
\text { 2013) }\end{array}$ & $\begin{array}{l}\text { Transnational alliances and } \\
\text { co-operations (e.g. } \\
\text { Anderson and O'Dowd, } \\
\text { 1999) }\end{array}$ \\
\hline Subnational (in scale) & City-region (e.g. Scott, 2001) & $\begin{array}{l}\text { Cross-border region (e.g. } \\
\text { Perkmann, 2003) }\end{array}$ \\
\hline
\end{tabular}


Figure 2: Going beyond the singular territorial/relational divide

a.

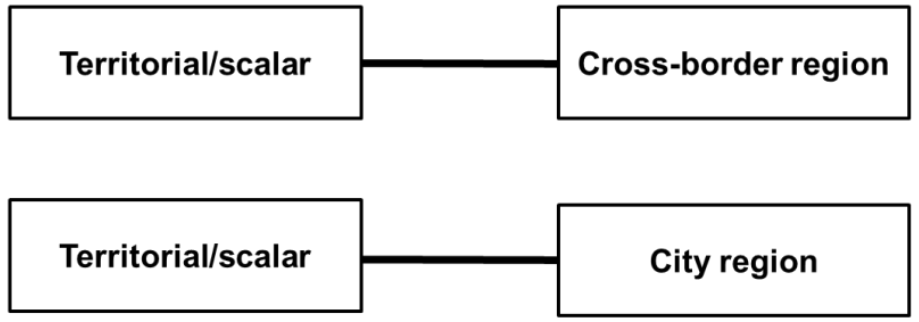

b.
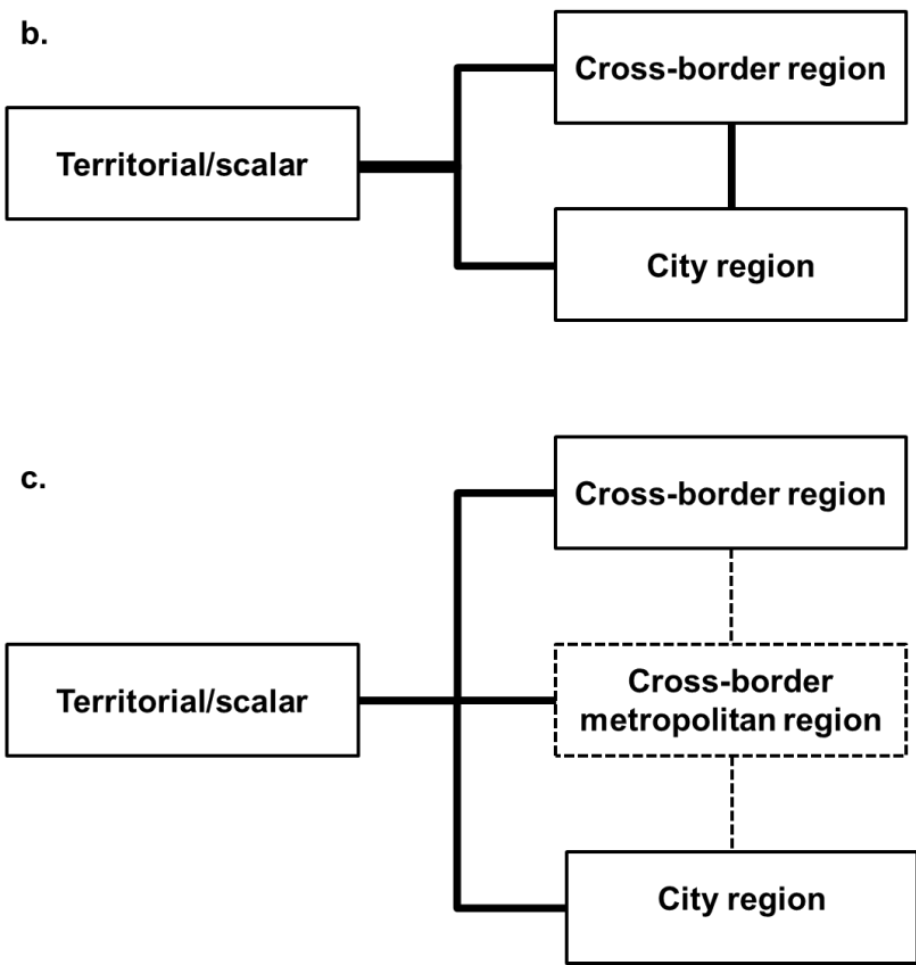
Figure 3: Leitbild - Growth and Innovation

\section{Concept: Growth and Innovation}

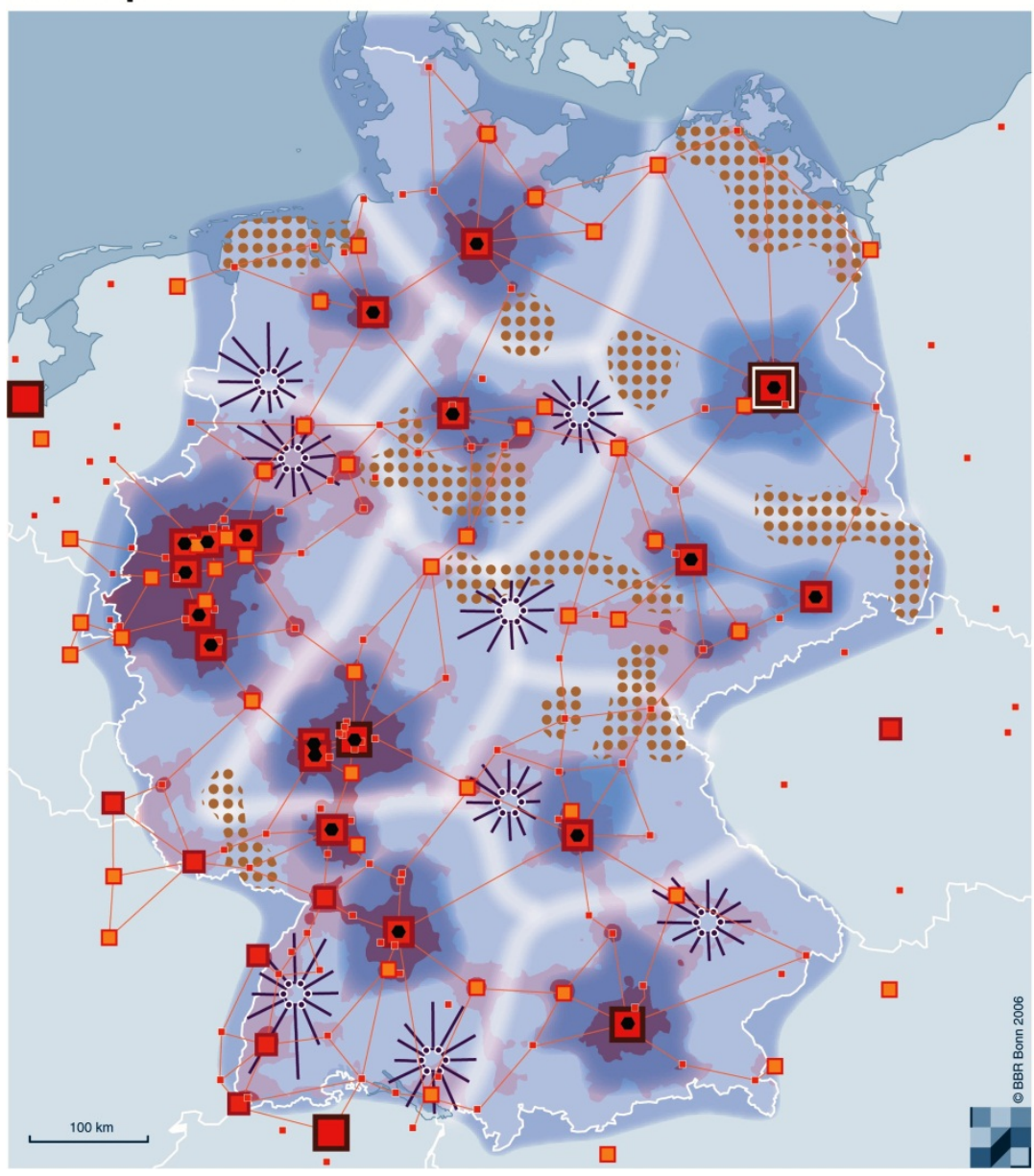

Metropolitan Regions

- Cores of the Capital Region and of existing European Metropolitan Regions Other cities with Metropolitan Functions Metropolitan Region

Areas of influence including rural areas Transition region between Metropolitan Regions

Growth regions outside Metropolitan Regions

ث:1

Stabilisation areas

$\because \because:$

Spatial structure

Central area of high density

Dense intermediate area

The map is illustrating the concept. However, the signature do not stand for determined planning.

\section{(Source: BMVBS/BBR, 2006: 13)}


Figure 4: Leitbild - Growth and Innovation with Model Projects

Karte 64

Impulse durch Modellvorhaben für das Leitbild Wachstum und Innovation

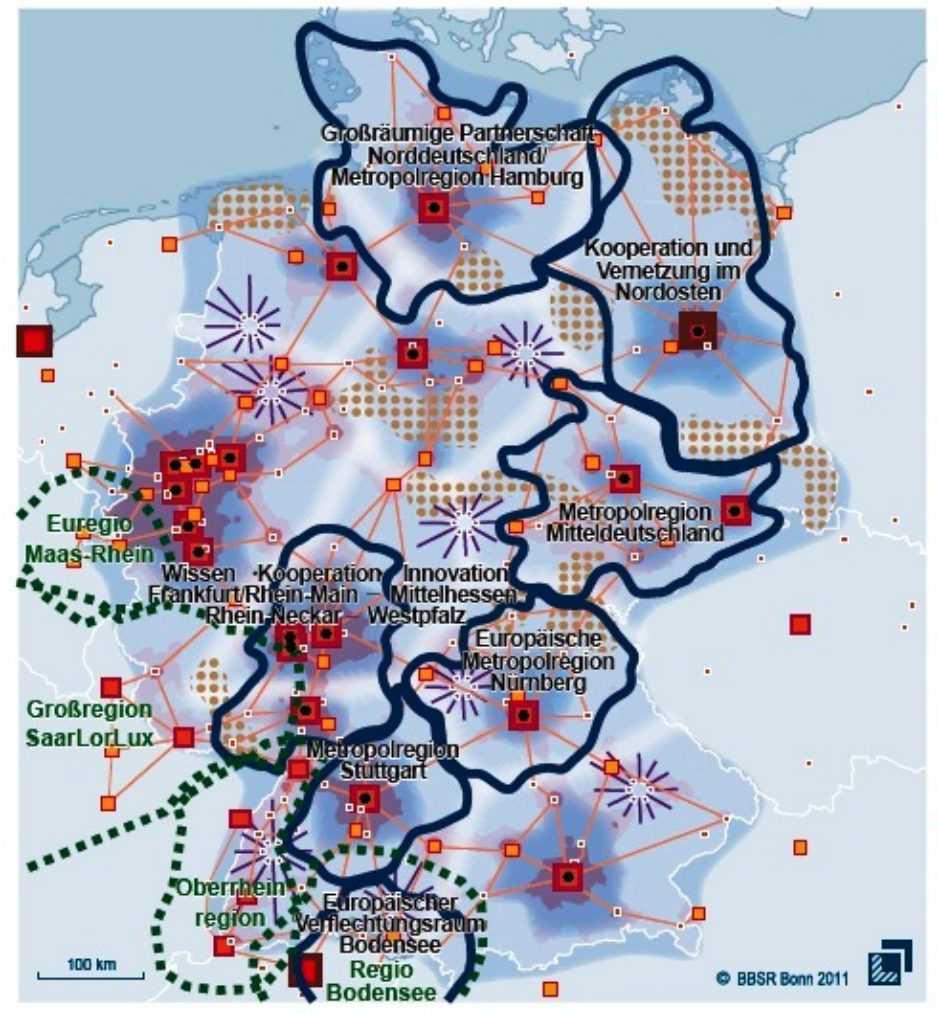

Modellvorhaben zum Themenfeld

Uberregionale Partnerschaften (2007 - 2010)

- Modellvorhaben zum Themenfeld

Uberregionale Partnerschaften in grenz überschreitenden Verflechtungsräumen $(2008-2010)$

Metropolräume

Kerne der Hauptstadtregion und der bestehenden europäischen Metropolregionen

$\square$. weitere Standorte von Metropolfunktionen

engerer metropolitane Verflechtungsraum

weiterer metropolitaner Verflechtungsraum einschließlich ländlicher Räume Übergangszonen zwischen metropolitanen Verflechtungsräumen

Wachstumsräume außerhalb engerer metropolitaner Verflechtungsräume $\frac{11}{11}$

Stabilisierungsräume

::

Raumstruktur

hochverdichteter Zentralraum verdichteter Zwischenraum

(Source: BBSR, 2012: 143) 
Figure 5: Leitbild - Growth and Innovation: Draft 1a

\section{Leitbild 1 - Entwurf 1a}

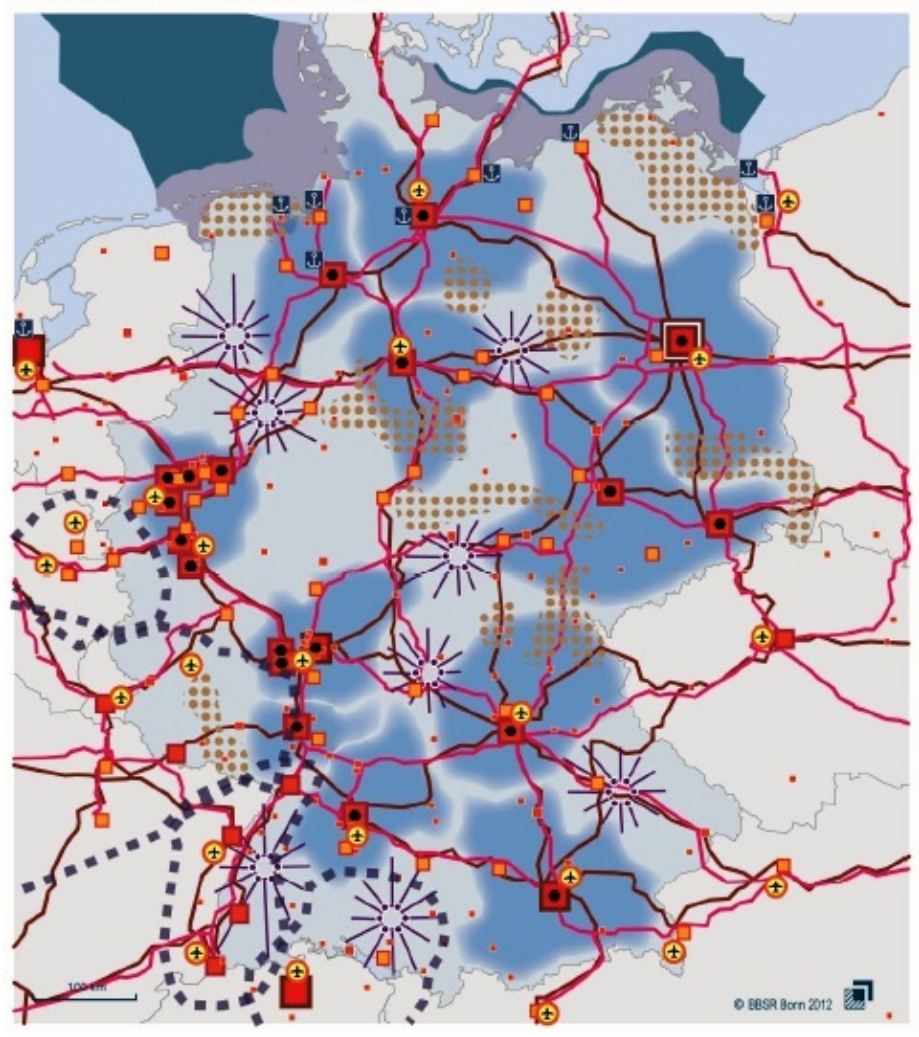

Metropolrăume

Terne der Hauptstadiregion und der bestehenden europaischen Metropolregionen weitere Standorte von Metropolfunitionen

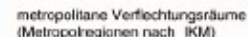

- $=$ -

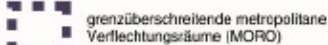

-. - .

Indliche und verstádterte

将

Räume mit besonderen Handlungserfordernissen

$\because:$ Stabiisierung

Verkehirsinfrastruktur

Europtisches Kemnetz - Schiene

- Eurcpaisches Kernnetz - Strasst

(4) Internationales Drehureuz im

6 Internationales Drehikeuz im

Seeverkehr

Planungsraum Meer und Kíse

Die Karte veranschaulicht das Leitbilid. Die Signaturen stellen jedoch keine planerischen Festlegungen dar.

(Source: IMeG Conference Presentation in Luxemburg, November 2012) 
Figure 6: Leitbild - Growth and Innovation: Draft 1b

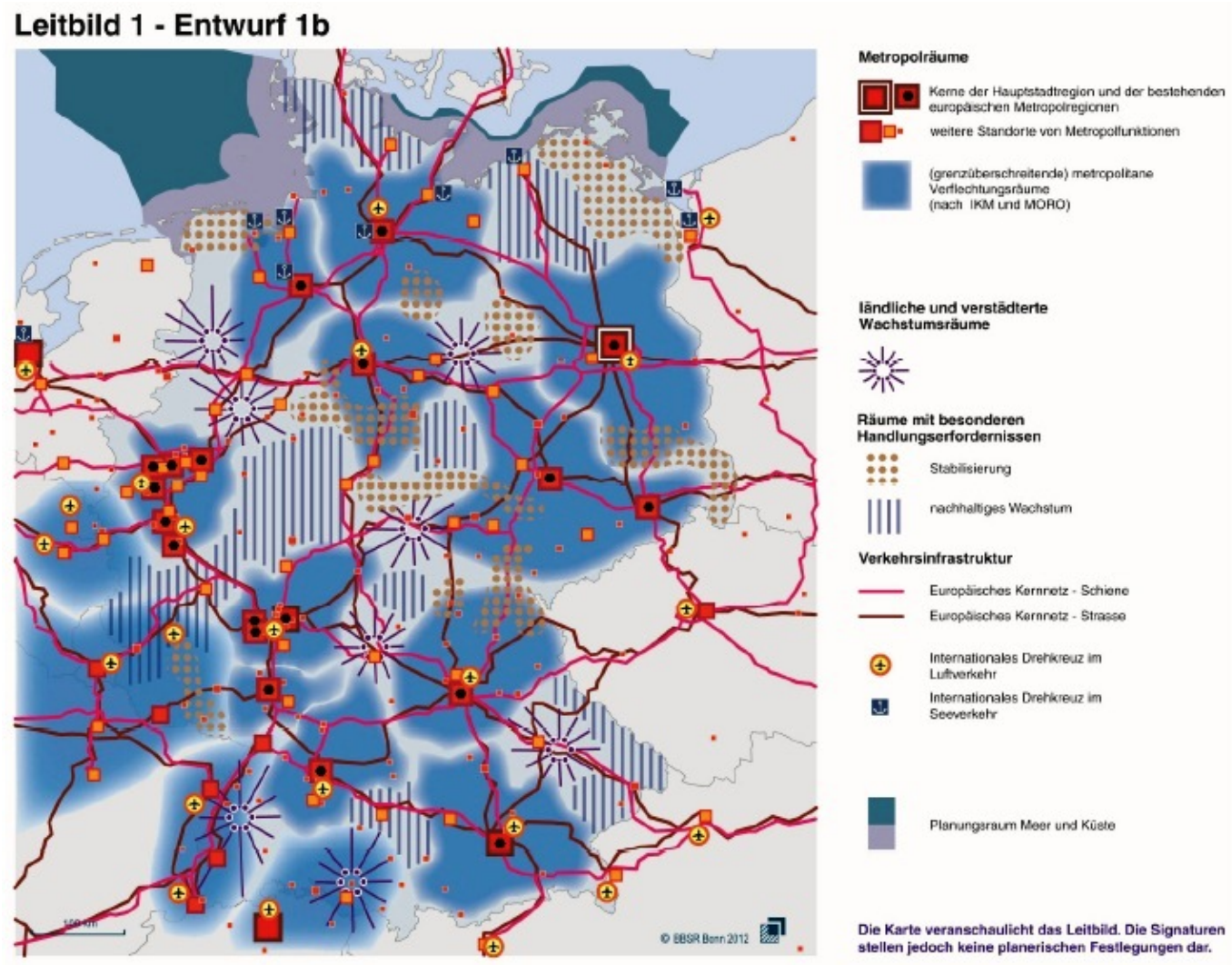

(Source: IMeG Conference Presentation in Luxemburg, November 2012) 
Figure 7: Leitbild - Strengthening Competitiveness: The Final Draft

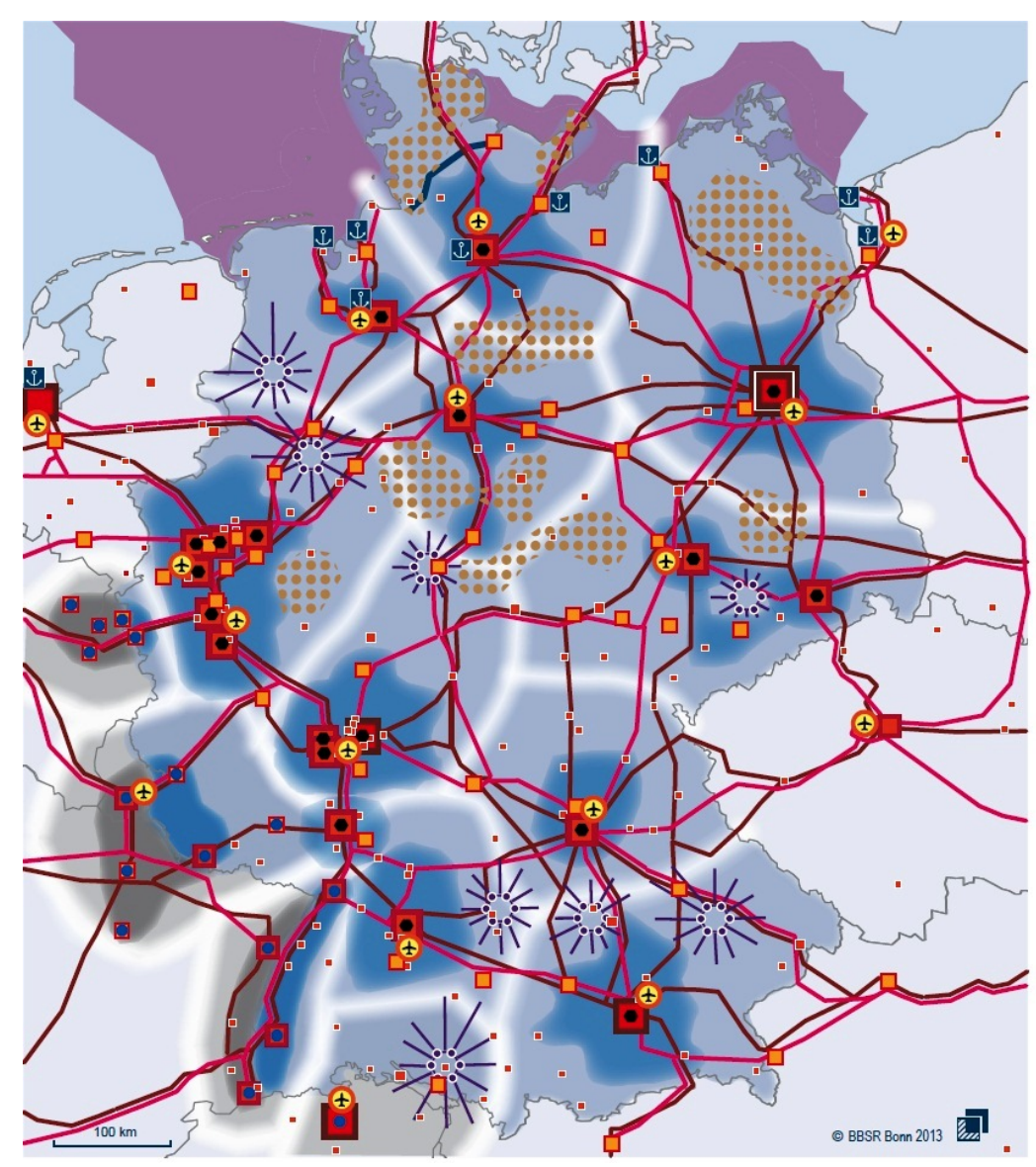

Metropolitan Regions

- Cores of the Capital Region and of existing European Metropolitan Regions

$\square=\quad$ Further Locations of metropolitan functions Immediate metropolitan spheres of influence Larger metropolitan spheres of influence including rural areas

Transition regions between metropolitan spheres of influence

Cores of the metropolitan border regions (IMeG) Immediate metropolitan spheres of influence in the metropolitan border regions (IMeG)

Metropolitan border regions (IMeG)

Rural und urbanized areas of economic growth 产:

Areas with special structural need for action $\because \because:$

Transport infrastructures

(Source: Results as agreed in the trialogue of 29 May 2013)

Road - Core network

Rail - Core network

๑) International airport - Core network

L. Maritime port - Core network

The Kiel Canal

Maritim planning area

The map is illustrating the concept. However, the signatures do not stand for determined planning.

(Source: IMeG, 2013: 11) 
' Illustrating this point, Perkmann never uses the word 'city' or 'metropolitan' in his 2003 article, while 'city' only appears once in his 2007 article.

ii We use the term 'metropolitan' instead of 'city' owing to the German planning discourse which refers to 'metropolitan regions'.

iii Balanced economic growth is still an aim of the federal state, with financial equalisation remaining an important mechanism for redistributing resources. The point is this has been overshadowed by the rise of competitiveness-oriented state spatial strategies in discussions of spatial planning policies. 